Aleksandr Kljucnikov,

Ph.D., University of Entrepreneurship and Law, Czech Republic

Mehmet Civelek,

Ph.D., University of Entrepreneurship and Law, Czech Republic

Vladimír Krajcík,

Ph.D., University College of Business in Prague, Czech Republic

Lubomír Kmeco,

Ph.D., University College of Business in Prague, Czech Republic

\title{
INNOVATIONS IN TOURISM MARKETING: SHARING ECONOMY PLATFORM
}

Abstract. This research summarizes the arguments and counterarguments within the scientific discussion on the issue of potential tax evasions and increased rental rates that one of innovative home-sharing platforms might causes. The study aims to find possible tax evasion that each property and each host can cause by considering creative activities in tourism marketing and a sharing economy platform, Airbnb in Prague. Besides, the authors identified the potential problems in the rental accommodation market. Systematization literary sources and approaches for solving the problem of sharing economy platforms indicate that although these platforms benefit for some economic, social and environmental issues, they pose some troubles in various markets. Regarding methodological tools of the research method, this paper used a web scraping technique to gain data from the Airbnb website. The authors analysed 13918 accommodations that were rented by 6768 Airbnb users between April 2016 and March 2017. In the study, the authors used the Microsoft Excel 2016 program and a model created by researchers to make calculations. The paper presented the results of an empirical analysis showing that in case the sensitive regulation of the number of nights will apply the potential tax incomes will lower only on $0.98 \%$ when considering accommodations and on $6.40 \%$ when considering users. In this case, 16832 rental units will appear in the long-term housing market. Moreover, tax evasion becomes more when considering each dwelling instead of each host because some users rented more than one rental accommodation. The research also empirically confirms and theoretically proves that that extended limits for overnight stays yield benefits for costs, supply and demand of rental housing. Those findings can be useful for governments, academicians that are interested in tourism marketing, firms in the accommodation industry that look for new marketing innovations and short or long-term housing market participants such as lessor and lessees. taxation.

Keywords: accommodation, tourism, marketing, Airbnb, innovation, home-sharing, Prague, sharing economy,

Introduction. During recent years, a new economic system, the namely sharing economy has gained significant importance due to its impacts on economic, social and environmental issues. Its considerable influences make individuals and businesses to be interested in this new trend. Therefore, many new players and entrepreneurs come into existence in various industries. Networks that are created by sharing economy platforms make all these service providers, shareholders and consumers to contact with each other to deploy idle resources. By doing so, sharing economy generates job opportunities for its users to be more innovative and enterprising and make them increase value addition for savings.

By being based on collaborative consumption idea, sharing economy also enables communities to be more responsive for environmental sustainability issue. For instance, instead of using their private cars, individuals can contact each other through a sharing economy network, travel together to reduce gas emission, and they can also save their money. For these reasons, sharing economy also changes customer behaviours and their consumptions patterns by focusing on the temporary use of resources instead of having or purchasing it. Sharing economy activities are performed in various sectors such as financing, dining, delivery, retail, entertainment and media, automotive and transportation and hospitability sectors, because of enabling lower costs and fees for its users.

Sharing economy activities have also been performed widely in the tourism and hospitality industries

Cite as: Kljucnikov, A., Civelek, M., Krajcik, V., \& Kmeco, L. (2020). Innovations in Tourism Marketing: Sharing Economy Platform. Marketing and Management of Innovations, 1, 11-25. http://doi.org/10.21272/mmi.2020.1-01 
and transform them by changing demands of its customers that are mainly visitors or travellers to find short-term accommodation options. These platforms enable local landlords to gain more income, while they provide benefits for guests to stay in these dwellings with lower costs. Although landlords and guests gain advantages by these sharing economy networks, hotels and local lessees face with obstacles by accessing these platforms to the markets. Moreover, the roles of governments and policymakers increase to fix these market distortions that home-sharing platforms can create. In this regard, one of the focuses of this study is to investigate disruptions that one of the home-sharing platforms namely AirBnB can cause in supply, demand and cost of short and long-term rental properties in Prague. Although there are other peers to peer home-sharing platforms such as Couchsurfing, VRBO, Flipkey, Wimdu, Homestay, Housetrip, Homeaway and 9flats, AirBnB is the market leader among online shared housing platforms. This online sharing economy platform is trendy in metropolises such as Paris, London, New York, Rio de Janeiro, Los Angeles, California and Sydney (Gurran and Phibbs, 2017). Similar abovementioned cities the clients of this home-sharing network by guests and travellers have become common to accommodate in Prague too.

The capital city of Czech Republic is Prague that 1.28 million inhabitants live, is one of the most visited cities around the world. According to news of CNN international (2018), Prague is 20th city regarding the number of arrivals in 2017 (8,806,700 arrivals). More than 7 million guests stayed in Prague hotels, hostels, guesthouses and campsites in 2016 and 2017. Around $86 \%$ of these visitors were foreigners in 2017. In the same year, 526 hotels, 48 hostels, 94 guesthouses, 20 camping sites and 99 other accommodation options existed in Prague, and they provided 41617 rooms, 90891 beds for their guests.

Moreover, 1096 longings presented accommodation services for tents and caravans (Prague City Tourism Annual Report, 2017). Because of being one of the most popular touristic destinations, the number of its visitors have also increased from year to year. Although many accommodation options exist in this city, the existence of Airbnb services, especially in peak times such as July and August could provide more opportunities for guests to stay. It could draw visitors' attention and make them stay longer than they expect because of the lower costs of residences in this platform in comparison with hotels.

Airbnb was founded in 2008 in San Francisco by Brian Chesky, Joe Gebbia and Nathan Blecharczyk. It presents more than 6 million accommodation options in more than 81000 cities and 191 countries. Airbnb is an online peer to peer platform that gathers hosts, visitors, shareholders and workers. Airbnb provides opportunities for individuals to be guests in different places from all over the world, meeting with local people and staying in various accommodation options. By using an online platform that has current technologies, millions of visitors and hosts can come together. Hosts generate incomes from their properties and abilities by being hospitable entrepreneurs (Airbnb, 2019) and they can also be called as microentrepreneurs who perform sharing economy activities while guests who stay in rental properties are consumers (Zhang et al., 2019). According to Forbes (2018), the marketing value of Airbnb is around $\$ 38$ billion. The Airbnb's cost has been compared with some famous hotel chains such as Marriot and Hilton by some studies. According to these researches, Airbnb is more valuable than both of those hotel chains (Shepperd and Udell, 2016; Wachsmuth and Weisler, 2018; Gurran, 2018; Dogru et al., 2017). Although its revenue was $\$ 2.6$ billion in 2017, the Airbnb's profit in 2020 was around $\$ 10$ billion (Heo et al., 2019).

Corresponding to AirBnB's impacts on imperfect competition issue, market entrance of Airbnb is perceived as a threat by especially hotels that serve with lower prices (Cheng, 2016; Zervas et al., 2017) because dwellings in Airbnb platform have negative influences on hotel revenues (Zervas et al., 2017; Gurran and Phibbs, 2017; Oskam and Boswijk, 2016) and workers of this kind of hotels (Oskam and Boswijk, 2016). Since some Airbnb hosts provide similar accommodation options for their guests, Airbnb services can create substitution effects (Zervas et al., 2017; Dogru et al., 2017) and influence hotel revenues by depending on location, season and hotel segment. Residential premises that are offered via Airbnb can also play complementary roles for the players of tourism and accommodation industries 
(Zervas et al., 2017). Moreover, providers of Airbnb services also do not need to fulfil requirements of safety (Coyle and Yeung, 2016; Sharp, 2018). Those facts can cause some problems regarding the quality and safety of rentals, protection of the consumers (Cheng, 2016) and imperfect competition between hoteliers and hosts of Airbnb (Sharp, 2018).

Moreover, policymakers become concerned about their tax revenues while firms in the hotel industry concern about their incomes (Cheng, 2016). Local residences are also worried about increasing trend in the costs of long-term dwelling and occupants can feel uncomfortable due to meeting with the high number of Airbnb guests in their places where they live (Coyle and Yeung, 2016). Local administrations become alarmed about increasing population, especially in centres of the cities and displacements of rental houses to Airbnb rentals that cause a decrease in the supply of long-term rentals (Coyle and Yeung, 2016).

To overcome these obstacles, governments limit the number of annual overnight stays in short term accommodations (Alizadeh et al., 2018) and apply taxation regarding these limits. Policymakers can also stop activities of home-sharing platforms in some cities to control prices of rentals and protect residential customers, hotel and real estate industries (Horn and Merante, 2017). Furthermore, policymakers can limit the number of dwellings that hosts are able to rent. In this regard, this study aims to determine potential tax evasion of AirBnB properties in Prague depending on yearly limits of overnight stays for each property and each host. Another objective of this study is to estimate the potential number of residential premises that might come to existence after setting yearly limits for overnight stays in these dwellings. By doing so, this study investigates supply, demand and costs of short and long-term rental properties and provides some sanctions that policymakers can apply. On the other hand, incomes of AirBnB hosts are also calculated by considering the booked days in the period between April 2016 to March 2017.

Regarding Airbnb properties and distortions that they cause in markets, many studies exist in the literature to analyze the competition between hotels and Airbnb accommodations (Zervas et al., 2017; Cheng, 2016). Some other studies also examine disruptions of AirBnB services in legal actions, labour market (Gurran and Phibbs 2017; Zervas et al., 2017), living conditions (Coyle and Yeung, 2016; Zuo et al., 2019) and taxation (DiNatale et al., 2018; Horn and Merante, 2017). However, the number of studies lack when it comes to AirBnB's impacts on the demand and supply of housing market and potential tax evasion that AirBnB rental dwellings might cause. Therefore, this study differs from other studies by looking at potential issues from a widening perspective and provide a reason for the increasing trend in the costs of long-term rentals in Prague.

Literature Review. Sharing economy make significant contributions to economies by creating or widening different activities with the usage of advancing technologies. The rapid increase of sharing economy has not only drawn businesses' attentions but also individuals have been interested in this phenomenon to take advantages of opportunities that collaborative consumption provides. For instance, unemployed people have become drivers of car-sharing platforms or have become hosts in house sharing activities. Apart from transportation and hospitability sectors, sharing economy activities are performed in various industries such as financing, dining and delivery because of enabling lower costs and fees for its users. Apart from its influences on the economy, it also has effects on social and environmental issues. For instance, it provides their users to directly contact other people through online platforms and by imposing collaborative consumption idea it enables people to the deployment of resources to reduce harmful environmental problems such as air pollution.

Sharing economy is also called collaborative consumption, peer to peer sharing, access-based consumption and commercial sharing systems in the literature. This new economic system provides individuals to do joint activities together to acquire or distribute to idle resources through a network mainly for temporary usage (Stuchly and Suta, 2019). Sharing economy platforms have been generated by the emergence of internet technologies that provide people to connect peer to peer platforms (Horn and Merante, 2017; Zuo et al., 2019; Melo et al., 2019). Those platforms differ from other traditional two-sided 
business models by including service providers that are not professional (Horn and Merante, 2017; Cheng et al., 2018). By enabling interaction through online or offline applications, information technologies, or web-based options, sharing economy platforms make users to gain their trusts (Cheng et al., 2018), to face with reduced transaction expenses (Eckhardt and Bardhi, 2015), gain services with lower costs (Tussyadiah and Pesonen, 2015) and to increase the sustainability of sharing economy activities (Zuo et al., 2019). Although the existence of short-term rental properties has some positive influences on tourism, job creation, income generation, economic growth, better decoration of ownership, and tax revenues, it has perceived negatively by some communities regarding its safety, legality and disruptive effects on rental markets. Existence of short-term rental services also makes guests cope with accommodation issues in the places where there are not any short-term housing opportunities (DiNatale et al., 2018).

Hospitality and tourism have been one the leading sectors by the emergence of sharing economy model. These sharing economy platforms in the tourism industry, enable visitors and hosts to connect to solve accommodation issues. Moreover, they allow guests to interact with local people that gain revenues from these services. As being a part of sharing economy, tourism and hospitality platforms has become a new phenomenon that has competed with famous hotel chains by widening their activities around the world and giving similar services (Cheng, 2016). Peer to peer accommodation platforms enables their guests to stay cheaper short-term residential promises (Balck and Cracau, 2015) that have more spaces in comparison with hotels. It is the main reasons why visitors select these accommodation opportunities (Quinby and Gasdia, 2014). Sharing-economy platforms also make individuals were more social by enabling them to have contacts and interactions with other people. Therefore, guests can directly contract with local hosts that monetize from their rentals through these online collaborative consumption options. These peer to peer accommodations platforms also make travellers save their money, and this fact enables them to stay longer time in short-term rentals and to do more touristic activities by visiting and travelling more places. For these reasons, these platforms change consumer behaviours (Tussyadiah and Pesonen, 2015).

Airbnb is the most common platform for sharing economy activities regarding peer to peer accommodation services. As being a part of sharing economy, Airbnb changes consumer behaviours by shifting demand for short-term accommodation options from hotels to home-sharing rentals. By doing so, it affects the hospitality and tourism industries, and it also increases the density of short-term rentals that are in widened geographical areas (Horn and Merante, 2017). Airbnb gets a commission from hosts and visitors (Gunter, 2018; Zervas et al., 2017) between $8 \%$ to 18\% for each reservation (Wachsmuth and Weisler, 2018). But guests are charged by Airbnb more than hosts (Zervas et al., 2017). The listings of Airbnb include properties such as villas, castles, penthouses (Wachsmuth and Weisler, 2018), spare bed in a living room, entire houses, shared or private offices. More than 200 million guests have stayed in those properties since the emergence of Airbnb (Dogru et al., 2017). Although only a few studies exist in the literature to analyse Airbnb services in Prague. Comparing Airbnb accommodations in Warsaw, Krakow and Prague, Skalska and Shcherbiak (2016) find that the guests of Airbnb rentals in Prague have more advantages than other visitors in Warsaw and Krakow regarding cost and utility.

Potential hosts announce their rentals through Airbnb's application or web page, set up prices and number of available days for the listed rentals (Zervas et al., 2017). Hosts can rent their entire home or some part of their properties through Airbnb, when they disuse these rentals (Horn and Merante, 2017) or when they are not in there such as when they are in vacation. Entrepreneurs can also make investments for existing Airbnb rentals in their market and rent these properties as short term dwellings (Gurran and Phibbs, 2017). Airbnb provides an opportunity for both hosts and guests to rate each other through this online platform (Gurran, 2018; Zervas et al., 2017). Therefore, hosts can increase their reputations by guests' evaluations on their services and characteristics of their rentals (Zhang et al., 2019). 
Similarly, hosts rate their guests at the end of the staying period and guests can use his/her reputation when looking for other dwellings from this online home-sharing platform (Zervas et al., 2017). Although the importance of Airbnb platform increases for hosts and guests, it causes some troubles in living conditions of residents and citizens, competition, market structure and tax revenues of governments, hotel industry, and regional administrations. With the purpose to overcome those issues, policymakers apply some regulations such as: charging hosts with taxes; limiting the number of nights that hosts can rent their residential premises during a year; setting also defines for the number of rentals that hosts can rent through Airbnb platforms. By doing so, policymakers also regulate short and long-term rental markets and influence supply and demand for rentals and costs of those dwellings.

Tax is one of the primary sanctions of policymakers on Airbnb listings to hinder disruptions in markets and imperfect competitions between players of hospitality and accommodation service providers. Owners and workers in the tourism and hotel industry are opposed to the Airbnb platform because hosts of rentals in this platform do not pay some taxes in various countries (Coyle and Yeung, 2016). Each government or policymakers apply a different kind of taxes and regulations to control and receive revenues from these activities (DiNatale et al., 2018). However, some hosts can create tax evasion if they are not registered as a freelancer or self-employed (Coyle and Yeung, 2016) or might not be exposed to face with policymakers' legislation (Cheng, 2016). But because of increases in the home-sharing activities that can be done by individuals and businesses, governments legislate to make differences among players who are subject to tax liability (Horn and Merante, 2017).

Regarding daily limits of Airbnb rentals, some cities from Europe and USA applied strict rules by limiting the number of nights for rentals during a year. New York, San Francisco and Portland were the initial cities who defined Airbnb properties for shorter daily limits (Alizadeh et al., 2018) 60 days is set as the limit in Baltimore (Richman, 2018), Amsterdam (Wachsmuth and Weisler, 2018) and Fairfax County (Olivo, 2018), while this limit is 90 days for London (Crommelin et al., 2018) and San Francisco (Olivo, 2018). Moreover, Barcelona, Paris (Zervas et al., 2017) and Montgomery let hosts rent their properties for 120 nights (Olivo, 2018). In Texas law, a hotel is identified as an accommodation option that can be rented more than 14 days, and hosts of Airbnb are also liable with this tax law (Zervas et al., 2017). New York allows for 30 nights, Arlington's limit for the number of nights for is 180 , and a host can only rent a house (Olivo, 2018).

Different from limits of nights for rentals, policymakers impose other sanctions on Airbnb dwellings. For instance, Hong Kong requires licenses for short term rentals that are less than 28 days and fines rentals that have not this license that includes safety, health. In London, a resident host can rent her/his property pays council tax that is different from the tax rates of companies (Crommelin et al., 2018). Berlin (Coyle and Yeung, 2016), San Francisco and Portland require registration for short term rentals. The rentals which are not registered forbid by policymakers.

Moreover, a maximum $25 \%$ of dwellings of an apartment can be rented through Airbnb platform in Portland (Gurran and Phibbs, 2017). Hosts in Brussels should gain acceptance of owners of the building or local government. Amsterdam set the limit for the number of guests who rent a rental. Hosts have to be the residence of Barcelona during the rental days. If they are not, they face with same legislation with hotels. Airbnb also accepted to get taxes in some places from tourists (Coyle and Yeung, 2016). A portal exists for French citizens to be registered as Airbnb hosts and, other residents of France can complain about Airbnb hosts who disturb them or breaking the rules. Hosts without registration have to pay a fine (Heo et al., 2019).

Corresponding to limits on the number of properties that a host can rent, Sharp (2018) reveals that during significant events such as World Cup hosts are limited by some quotas to rent their properties through Airbnb listings to preserve the supply of permanent residences. Barcelona sets limits similar with France as the owners can only rent their permanent residential premises and they have to stay the nights 
with their guests that can rent maximum two rooms in the same dwelling (Llop, 2016). Moreover, policymakers in Baltimore limit AirBnB hosts to rent only two properties, including their permanent residence (Richman, 2018). Some debates came into existence regarding professional hosts that have rentals those hosts rent more than one and most of the listed dwellings. For this reason, Attorney-General of New York called those activities as illegal, and Airbnb was required to give their data of their users in 2015 (Alizadeh et al., 2018; Gurran and Phibbs, 2017).

Regarding Airbnb's impacts on long term housing supply, residents perceive Airbnb's rentals as a threat to the housing market (Cheng, 2016). It is because, instead of renting their homes for the long term, landlords can rent their houses for a short time and this fact can cause lack of available and affordable apartments for residents to stay in the long run. Thus, the supply of long-term rental dwellings decreases while the amount of short-term rental properties increases (Cheng, 2016; Sharp, 2018; Alizadeh et al., 2018). This decreasing supply in permanent rental dwellings has created issues in New York, San Francisco, Los Angeles, Berlin (Schafer and Braun, 2016), and Sydney (Gurran and Phibbs, 2017).

But, target market or locality where the home-sharing market is in existence are vital factors that impact demand and supply of dwellings in that region. For instance, if some guests from New York looking for accommodations for the short term in Boston, they will not be concerned about the permanent rentals in Boston and consumers who search for long term rentals in New York will be not influenced. However, Boston's home-sharing market will be affected by the demands of those visitors (Horn and Merante, 2017). On the other hand, if the density of Airbnb dwellings is more in city centres than suburban regions, the prices of houses in city centres will be increased more than other residences that are located in suburban areas (Sheppard and Udell, 2016). By examining Airbnb rentals in London, Quattrone et al. (2016) confirm the existence of a high correlation between Airbnb listings and closeness of residential promises to city centres or places where significant events or activities held on. While lack of Airbnb listings exists in highend neighbourhoods, many dwellings are located in touristic places (Alizadeh et al., 2018).

Moreover, if the demand for Airbnb rentals and revenues of hosts increase in city centres, the values of houses can be decreased in those local places. By directing most of the visitors to in urban areas, Airbnb raises the number of people who live in these areas, so prices of housings increase. This issue makes local authorities and local residences to be against Airbnb rentals (Sheppard and Udell, 2016).

According to DiNatale et al. (2018), when the percentage of short-term rentals is higher than $5 \%$ of total dwelling stock, cities can face problems regarding the supply of residential premises. But this percentage is smaller for rent, entire houses. By examining all Airbnb listings in the USA, Barron et al. (2018) find a positive relationship between increases in Airbnb listings and costs of houses and rentals. This positive relationship between growth in Airbnb listings and rental rates are also confirmed by the studies of Lee (2016) and Horn and Merante (2017) that analyse rental markets in Los Angeles and Boston respectively. Barron et al. (2018) and Horn and Merante (2017) also highlight that average cost for a night for Airbnb rentals was two times higher than the average price for a night in dwellings that were rented for a month. The reasons for those increase in rental rates depend on choices of landlords to rent their properties for short term and their acceptance to stay with guests in the same house. Despite increasing costs in long term properties for local people, both visitors and hosts gain advantages from the Airbnb platform by having cheaper accommodation options and by getting more revenues respectively (Barron et al. 2018). By analysing Airbnb services in Boston, Horn and Merante (2017) find that most of the hosts only rent their own houses to generate more income. However, the researchers also find that almost half of the dwellings in Boston have rented by hosts that let more than one property. This result shows that commercial operators played an active role in home-sharing activities and this fact causes a reduction in the supply of long-term available dwellings for residents and make pressures on owners of residential premises to rent their properties for the short term. 
Concerning the influences of Airbnb listings on the hotel industry, Airbnb's access on the accommodation markets has risen the number of rooms that are available for potential guests. In case of having stable demand in the tourism and hospitality industry, the increase in the supply that Airbnb causes, reduces costs and revenues for hotels and other businesses in those sectors (Dogru et al., 2017) can weaken the pricing power of hotels. It is because Airbnb rentals can provide similar services with some hotels that serve for the lower end of the market (Zervas et al., 2017). On the other hand, the advantages of the Airbnb platform have contended by some studies. For instance, Alizadeh et al., (2018) and Gurranand Phibbs (2017) infer that revenues from Airbnb activities support hosts to pay their mortgage credits, upkeep costs. Therefore, hosts can protect the value of their dwellings (Alizadeh et al., 2018). Shepperd and Udell (2016) also posit that the existence of Airbnb listings in a city rises values of residences, and this fact provides advantages for landlords. Hosts that are in the lower-income segment can also gain these incomes to afford their other expenditures (Alizadeh et al., 2018). Moreover, guests of Airbnb rentals, create values for national economies by making contributions to tourism, the hospitality industry, and local firms.

According to report o Airbnb, visitors do not prefer staying longer in case of the nonexistence of Airbnb rentals, and they express that even there are not any rental residents in Airbnb listings they will not stay in hotels (Heo et al., 2019). Although Airbnb' access to markets can create problems for businesses and other accommodation options in tourism and hospitality industry, they expand accommodations opportunities for tourists when demand increases to a larger extend, especially for events such as conferences. Because Airbnb listings are also located in different regions of the cities, visitors can also spend their money in those places (Gurran and Phibbs, 2017). On the other hand, by analysing Airbnb and hotels in Korea, Choi et al. (2015) confirm that Airbnb does not decrease revenues of hotels. Similarly, the study of Heo et al. (2019) clarifies that although the number of Airbnb rentals has risen to a large extent in central cities, the revenues for each room does not change. Thus, Airbnb does not create risks for hotel revenues (Dogru et al., 2017).

Methodology and research methods. The objective of this study is threefold. The first one is to find out total and average revenues of the lessors regarding the number of booked days of their dwellings that have rented in Prague through the Airbnb platform. The second purpose of this research is to determine potential tax evasion of Airbnb rental properties in case of setting limits for the number of overnight stays that guests can accommodate during a year in each park and each host's rentals. When it comes to the last goal, the study aims to investigate the potential number of AirBnB accommodations that might emerge in Prague short-term rental market and revenues from them in case of setting daily limits that rentals can be rented in a year. The number of booked days of AirBnB residences and all yearly limits for each lessor and each property regarding the number of overnights that visitors can stay is counted for $10,20,30$ and 40 days.

In line with these selected aims, three scientific hypotheses were set up by authors considering previous studies and predictions of experts. These hypotheses are presented below:

$\mathrm{H} 1$. In case of taxing each AirBnB accommodation unit regarding their number of overnight stays in a year, the amount of potential tax evasion will be less than 500 million Czech Crowns for each case.

$\mathrm{H} 2$. In case of taxing each AirBnB host by specifying annual limits for the number overnight stays that they can rent their dwellings, the amount of potential tax evasion will be less than 500 million Czech Crowns.

H3. A positive relationship exists between increases in Airbnb listings and rental rates.

This study focused on transactions that performed through the Airbnb platform, was between the dates of 01.04.2016 to 31.03.2017. Web scraping technique was applied by this research to gain the data from the website of Airbnb and this method made researchers have detailed information about listings, booked days and revenues of from each reservation. This web scraping method has also been used by studies of 
Crommelin et al. (2018) and Wegmannand Jiao (2017) that focus on AirBnB activities. The IT experts created a web scraping tool for this study, and they observed transactions in Prague from the website of Airbnb for two months. The details about these transactions also validated by using information from AirDNA data. AirDNA data has an algorithm that separates booked and blocked days for rentals that are not available.

For this reason, it gives specific information to be more informed about the availability of Airbnb accommodations (Wachsmuth and Weisler, 2018; Crommelin et al., 2018). In this selected period, 8943 Airbnb service providers registered 18586 rentals in Prague although guests and visitors stayed 13918 of these dwellings. Therefore, this research mainly focused on these 13918 rented accommodations that were provided by $6768 \mathrm{AirBnB}$ users. 10406 accommodations were entire home while other accommodation options were private or shared rooms. The Microsoft Excel program made the calculations of this study.

To model tax evasion, hosts in AirBNB platform are presumed as a self-employed entrepreneur by the researchers. But those hosts are not categorized as a legal entity. In this line with these assumptions, AirBnB service providers in Prague will be liable to pay income tax for individuals, and value added tax, social insurance and health insurance taxes and local tax that is $15 \mathrm{CZK}$ for each guest.

Article 7 Act No.: 586/1992 Coll. Describes income taxes for taxpayers who gain revenues as selfemployed from accommodation activities. According to Income Tax Act, ITA taxpayers who increase incomes as an independent entrepreneur can apply for flat tax rate if they do not spend their revenues for security, acquisition and maintenance expenses that can reach $60 \%$ of their incomes in the taxable period. However, those expenses can be maximum 1.200.000 CZK. Although, the flat income tax rate is considered as $15 \%$ in this research and incomes that are 40 times higher than the average salary (1.296.288 CZK in 2016) are subject to additional tax 7\% solidarity tax that is identified by ITA in the Section 16a. Regarding tax deduction, the proposed tax model of this research pays regard to ITA Section $35 \mathrm{ba}(1, \mathrm{a})$ and the amount of tax deduction in this fact is determined as $24840 \mathrm{CZK}$.

Corresponding to Value Added Tax (VAT), Section 6 (1) in Act No. 235/2004 Coll. is applied by this research. According to this Act, taxpayers are subject to VAT if their turnovers in 12 months (in a row) go over the limit of 1 million CZK. The rate for VAT is set as $15 \%$ in this study by considering to VAT Act $\S$ 47. Concerning pension insurance premium rate for self-employment activities, Act No. 155/1995 is based on, and $28 \%$ pension insurance and $1.2 \%$ state employment policy rates are considered to evaluate pension premium rate in this study. The calculation for social security tax amount is also based on $50 \%$ of the income of self-employed entrepreneurs that they gain from their business and self-employment operations after the reduction of expenditures mentioned above, such as maintenance. The base for evaluation of social insurance premium was up to $1.296 .288 \mathrm{CZK}$ in 2016. When it comes to health insurance, the same calculation method is used with social protection, and the rate for it is $13.5 \%$. Furthermore, the local fee in Prague for per person is 15 CZK per day. Payment for the local price is determined by Act No. 565/1990 by relating it to Decree No. 27/2003 and administered by Act No. 280/2009 Coll.

All those considered taxes are added to the final model of this study to calculate possible tax evasion that rentals of AirBnB platform cause. Microsoft Excel program is performed to make calculations for all those tax rates, incomes, revenues and potential tax evasions for each specified limit.

Results. To hit the first target of this research, total and average incomes from Airbnb residential premises that rented for more than 10, 20,30 and 40 days were calculated separately. CZK/USD exchange rate was considered 24.53 as the Czech Ministry of finance described it in 2016.

Table 1 shows total revenues from total and average taxes from all AirBnB accommodations in Prague concerning the number of booked days. The total income that gained from AirBnB rentals in Prague reached $\$ 86.348 .464$ in the selected period. Majority of this revenue was obtained by dwellings $(82,53 \%)$ 
that rented for more than ten days. When it comes to average revenue from per property, the average incomes were the highest for the residential premises that rented for more than 40 days $(\$ 9994,07)$.

Table 1. Total and average revenues of Airbnb rentals regarding the number of booked days between April 2016 to March 2017

\begin{tabular}{|c|c|c|c|}
\hline Number of booked days & Share of units & Total revenue USD & $\begin{array}{c}\text { The average revenue per } \\
\text { unit }\end{array}$ \\
\hline 10 days or less & $17,47 \%$ & $\$ 1.060 .006$ & $\$ 436,04$ \\
More than 10 days & $82,53 \%$ & $\$ 85.288 .458$ & $\$ 7424,78$ \\
More than 20 days & $71,63 \%$ & $\$ 83.544 .917$ & $\$ 8380,47$ \\
More than 30 days & $63,90 \%$ & $\$ 81.533 .705$ & $\$ 9167,27$ \\
More than 40 days & $56,73 \%$ & $\$ 78.913 .188$ & $\$ 9994,07$ \\
\hline Without limits & $100 \%$ & $\$ 86.348 .464$ & $\$ 6.204,09$ \\
\hline
\end{tabular}

Sources: developed by the authors based on their calculations (2019).

In an attempt to achieve the second aim of this research, a model that calculates potential tax evasion of AirBnB dwellings is generated by including income tax, VAT, social and medical insurance premiums and other mentioned taxes in methodology part of this study. Taxpayers were separated concerning their taxable incomes. By doing so, their tax liabilities were identified by applying the rates of taxes mentioned above. For instance, the solidarity tax was applied for taxpayers whose annual turnover was 40 times higher than the average salary in the Czech Republic. Airbnb rental properties that were rented for more than 10, 20, 30 and 40 days in a year were taken into consideration and potential tax evasion for each limit for the overnight staying period were calculated separately. The results of these cases were indicated in Table 2.

Table 2. Potential tax evasion when taxing each AirBnB rental

\begin{tabular}{|l|c|c|c|c|}
\hline \multirow{2}{*}{ Tax or insurance premium } & \multicolumn{4}{|c|}{ The limits for rental periods of each dwelling in a year } \\
\cline { 2 - 6 } & $\begin{array}{c}\text { More than } \\
\text { 10 days }\end{array}$ & $\begin{array}{c}\text { More than } \\
\mathbf{2 0} \text { days }\end{array}$ & $\begin{array}{c}\text { More than } \\
\mathbf{3 0} \text { days }\end{array}$ & $\begin{array}{c}\text { More than } \\
\text { 40 days }\end{array}$ \\
\hline Income tax (CZK) and share of & 119.628 .533 & 119.628 .533 & 119628533 & 119.560 .703 \\
turnover (\%) & $(5,67 \%)$ & $(5,71 \%)$ & $(5,75 \%)$ & $(5,81)$ \\
\hline Including solidarity tax (CZK) & 23.317 .778( & 23.317 .778 & 23.317 .778 & 23.317 .778( \\
and share of turnover (\%) & $1,11 \%)$ & $(1,11 \%)$ & $(1,12 \%)$ & $1,13 \%)$ \\
\hline VAT (CZK) and share of & 158.570 .526 & 158.570 .526 & 158.570 .526 & 158.356 .315 \\
turnover (\%) & $(7,52 \%)$ & $(7,56 \%)$ & $(7,62 \%)$ & $(7,69 \%)$ \\
\hline Social Insurance Premium & 115.144 .513 & 114.365 .166 & 113.442 .578 & 112.238 .725 \\
(CZK) and share of turnover (\%) & $(5,46 \%)$ & $(5,46 \%)$ & $(5,45 \%)$ & $(5,44 \%)$ \\
\hline Medical Insurance Premium & 68.797 .542 & 68.437 .116 & 68.010 .497 & 67.453 .842 \\
(CZK) share of turnover (\%) & $(3,26 \%)$ & $(3,26 \%)$ & $(3,27 \%)$ & $(3,28 \%)$ \\
\hline Total (CZK)and share of & $\mathbf{4 6 2 . 1 4 1 . 1 1 4}$ & $\mathbf{4 6 1 . 0 0 1 . 3 4 1}$ & $\mathbf{4 5 9 . 6 5 2 . 1 3 4}$ & $\mathbf{4 5 7 . 6 0 9 . 5 8 5}$ \\
turnover (\%) & $(\mathbf{2 1 , 9 1 \% )}$ & $\mathbf{( 2 1 , 9 9 )}$ & $\mathbf{( 2 2 , 0 9 )}$ & $(\mathbf{2 2 , 2 2} \%)$ \\
\hline
\end{tabular}

Sources: developed by the authors based on own calculations (2019).

As shown in Table 2, the decreases in the limit days increase the tax evasion. For instance, in the case of calculating tax evasion of accommodations that were rented for more than ten days, the amount 
of tax evasion became the highest among other limits. But changing limits in the number of overnight stays from 10 to 40 days lower potential tax income of the state only $0.98 \%$. Moreover, to calculate possible tax evasion for local tax, the study considers multiplication of the total number of booked days in the selected period, the average number of guests for each booking and the local fee for each person. Therefore, 1.112.702 scheduled days is multiplied by 15 CZK local tax and by 1,5 or 2 guests. Thus, the local cost that policymakers in Prague should receive around $27,263,295$ to $36,351,060$ for a year. Even those amounts add to the potential tax evasion of each case, and total tax evasion is still lower than 500 million $\mathrm{CZK}$. For this reason, this study fails to reject $\mathrm{H} 1$ hypothesis. However, some hosts might have been not willing to face tax liabilities (Cheng, 2016). Therefore, setting tax free limit just for ten days can reduce the number of hosts that offer accommodations through Airbnb platform.

According to Table 3, tax evasion for each scenario is less than 500 million CZK and adding the local tax that differs around $27,263,295$ to $36,351,060$ for a year does not make these amounts to exceed 500 million CZK. For these reasons, this research fails to reject the $\mathrm{H} 2$ hypothesis. The results also indicate that applying the different number of booked days as from 10 to 40 days decrease potential tax revenues around $6.40 \%$.

Table 3. Potential tax evasion when taxing each Airbnb host

\begin{tabular}{|c|c|c|c|c|}
\hline \multirow[b]{2}{*}{ Tax or insurance premium } & \multicolumn{4}{|c|}{ The limits for rental periods in a year } \\
\hline & $\begin{array}{l}\text { More than } \\
10 \text { days }\end{array}$ & $\begin{array}{l}\text { More than } 20 \\
\text { days }\end{array}$ & $\begin{array}{c}\text { More than } 30 \\
\text { days }\end{array}$ & $\begin{array}{c}\text { More than } 40 \\
\text { days }\end{array}$ \\
\hline $\begin{array}{l}\text { Income tax (CZK) and share } \\
\text { of turnover }(\%)\end{array}$ & $\begin{array}{c}16.812 .960 \\
(0,80 \%) \\
\end{array}$ & $\begin{array}{c}16.812 .960 \\
(0,82 \%) \\
\end{array}$ & $\begin{array}{c}16.806 .675 \\
(0,84 \%) \\
\end{array}$ & $\begin{array}{c}16744125 \\
(0,87 \%) \\
\end{array}$ \\
\hline $\begin{array}{l}\text { Including solidarity tax (CZK) } \\
\text { and share of turnover (\%) }\end{array}$ & $\begin{array}{c}0 \\
0 \% \\
\end{array}$ & $\begin{array}{c}0 \\
0 \% \\
\end{array}$ & $\begin{array}{c}0 \\
0 \% \\
\end{array}$ & $\begin{array}{c}0 \\
0 \% \\
\end{array}$ \\
\hline $\begin{array}{l}\text { VAT (CZK) and share of } \\
\text { turnover }(\%)\end{array}$ & $\begin{array}{c}18.175 .767 \\
(0,87 \%) \\
\end{array}$ & $\begin{array}{c}18.175 .767 \\
(0,89 \%) \\
\end{array}$ & $\begin{array}{c}18.175 .767 \\
(0,91 \%) \\
\end{array}$ & $\begin{array}{c}17.961 .556 \\
(0,93 \%) \\
\end{array}$ \\
\hline $\begin{array}{l}\text { Social Insurance Premium } \\
\text { (CZK) and share of turnover } \\
(\%)\end{array}$ & $\begin{array}{c}121.039 .326 \\
(5,79 \%)\end{array}$ & $\begin{array}{c}118.552 .178 \\
(5,78 \%)\end{array}$ & $\begin{array}{c}115.678 .722 \\
(5,78 \%)\end{array}$ & $\begin{array}{l}111.944 .228 \\
(5,78 \%)\end{array}$ \\
\hline $\begin{array}{l}\text { Medical Insurance Premium } \\
(\mathrm{CZK}) \text { share of turnover }(\%)\end{array}$ & $\begin{array}{c}55.962 .154 \\
(2,67 \%) \\
\end{array}$ & $\begin{array}{c}54.811 .995 \\
(2,67 \%) \\
\end{array}$ & $\begin{array}{c}53.483 .302 \\
(2,67 \%) \\
\end{array}$ & $\begin{array}{c}51.756 .545 \\
(2,67 \%) \\
\end{array}$ \\
\hline $\begin{array}{l}\text { Total (CZK)and share of } \\
\text { turnover }(\%)\end{array}$ & $\begin{array}{c}211.990 .20710 \\
13 \%\end{array}$ & $\begin{array}{c}208.352 .90010 \\
16 \%\end{array}$ & $\begin{array}{c}204.144 .46610 \\
20 \%\end{array}$ & $\begin{array}{c}198.406 .45410 \\
25 \%\end{array}$ \\
\hline
\end{tabular}

Sources: developed by the authors based on own calculations (2019).

These total amounts in Table 3 are less than half of the volumes of tax evasion when tax applications are performed for each dwelling. The reason for this is considering only hosts instead of each residence in the calculation of tax evasion cause to exclude $28.9 \%$ of users' houses because they provided a minimum of two dwellings through AirBnB platform. For instance, 529 lessors rented a minimum of 5 residences in Prague. It seems that these users are only liable for their one rental and so their other rentals are tax-free. For these reasons, by basing on limits for only hosts cause to have lower tax evasion than setting deadlines for each rental dwelling.

The total number of reservations days in the specified period was 1.211 .702 for all accommodation options of Airbnb services in Prague. In case of setting limits for annual overnight stays yearly for Airbnb accommodations for 10,20,30 and 40 days, the entire reservation days will be divided to these limits to find the number of required short-term dwellings to fulfil demands of guests. Therefore, it is assumed that 
all accommodations are booked for 10, 20,30 and 40 days. The existing rental flats in Prague was 13461 in 2016. By subtracting the number of current rentals from the required number of accommodations, the number of apartments that might appear can be found.

Moreover, total revenues for each scenario is calculated by multiplying the required number of rentals and the average income for per unit. The ordinary tax per unit was calculated by dividing total revenues of rentals dwellings that were rented by $10,20,30$ and 40 days or less to the numbers of rentals that fall to each of these limits. For instance, the total revenue of the rental accommodations that were rented for 20 or fewer days was $\$ 2.803 .547$, and the number of these specified rentals was 3949 . By dividing $\$$ 2.803.547 to 3949, the average revenue of dwellings that were rented for 20 or fewer days was found as $\$ 709.94$. Similarly, all calculations were done by researchers and provided in table 4 . According to these findings, total revenue is the highest when the yearly staying limit for each property is ten days.

When the limit days increase, the needed number of the Airbnb accommodations and total revenues from these rentals decrease. On the other hand, as indicated in Table 4, low reservation limits for each accommodation option increase the number of required Airbnb rentals. The number of potential rental dwellings that can appear in Prague differs from 16832 to 107710 when changing limits from 10 to 40 days. This fact can cause issues regarding supply of long-term rentals. It is because of the positive association between the increases in Airbnb listings and rental rates. For instance, if it is assumed that all dwellings will be rented for ten days, the average daily rental rate for these residential premises will be around $\$ 43,60$ ( $\$ 436,04 / 10$ days) while the average daily rental rate for dwellings that are rented for 40 or fewer days will be $\$ 30,87$ ( $\$ 1234,69 / 40$ days).

Table 4. Potential number of flats and their revenues when limiting annual booked days for per accommodation

\begin{tabular}{|c|c|c|c|c|}
\hline $\begin{array}{c}\text { Number of } \\
\text { scheduled days } \\
\text { per year }\end{array}$ & $\begin{array}{c}\text { Required No. } \\
\text { of Rentals }\end{array}$ & $\begin{array}{c}\text { Number of } \\
\text { apartments that } \\
\text { may appear }\end{array}$ & $\begin{array}{c}\text { Average } \\
\text { Revenue per unit }\end{array}$ & Total Revenue \\
\hline 10 days or less & 121171 & 107710 & $\$ 436,04$ & $\$ 52.835 .403$ \\
20 days or less & 60586 & 47125 & $\$ 709,94$ & $\$ 43.012 .425$ \\
30 days or less & 40391 & 26930 & $\$ 958,35$ & $\$ 38.708 .715$ \\
40 days or less & 30293 & 16832 & $\$ 1234,69$ & $\$ 37.402 .464$ \\
\hline
\end{tabular}

Sources: developed by the authors based on their own calculations (2019).

Moreover, the number of rentals that might appear in short-term accommodation market in Prague is 107710 when the reservation limits up to 10 days for a year in dwellings. But the potential number of AirBnB flats is 30293 in case of having a limit for 40 days staying in each residence. In this regard, this study accepts $\mathrm{H} 3$ hypothesis that is set up as increases in Airbnb listings and rental rates are positively associated. Therefore, this study finds compatible results with the study of Barron et al. (2018), Horn and Merante (2018) that also confirm the positive relationship among these variables. But when it comes to the long-term supply of rentals, the increasing trend in the number of Airbnb dwelling decreases the amount of long-term accommodations. Therefore, the costs of long-term residential premises also increase, and citizens and residents face difficulties to afford rental prices and to find available accommodation options for themselves. As those problems have experienced by some cities in USA and Europe, if the state applies a regulation to limit rental days for Airbnb accommodations in Prague just for ten days, habitats in this city also encounter with these obstacles. Therefore, policymakers should apply regulations that limit landlords to rent their properties for short term accommodations and govern them to rent their dwellings for long terms. 
According to Trading Economics, House Price Index of the Czech Republic has increased during the last five years. This index gauges the variations in the costs of single-family dwellings. Moreover, the average monthly rental fees of a $2+1$ flat in the city centre of Prague is around $25000 \mathrm{CZK}$ while the average net salary is around 30000 CZK in Prague. The costs of apartments have increased by $40 \%$ in the last four years. When it comes to the prices of rooms, it is around $12000 \mathrm{CZK}$. These amounts confirm that how rental houses and apartments are expensive in Prague (Expats News, 2018). Therefore, setting fewer limit days for overnight stays might be the reason for increases in the costs of long-term rental dwellings in Prague due to the increasing number of Airbnb properties to satisfy the demand. Instead of setting the limit for 30 days for Prague, policymakers can extend this limit to make hosts rent their houses for longer terms.

This study has also presented in Table 4 that increases in the annual limit of the number of overnight stays in AirBnB accommodations decrease the required AirBnB dwellings. Revenues of hotels decline (Zervas et al., 2017; Coyle and Yeung, 2016; Alizadeh et al. (2018) and costs of accommodations increases (Shepperd and Udell, 2016; Alizadeh et al., 2018) where the number of Airbnb dwellings are high. For this reason, increasing the limits of an overnight stay for AirBnB rentals might not impact the incomes of hotels. However, the majority of people who arrive in Prague are foreigners (86\% in 2017). Therefore, most of these visitors can prefer staying in the city centre, and this choice might be another reason why the costs of accommodations have increased during the last years in Prague. Moreover, policymakers can apply additional taxes such as occupancy tax for hosts who want to rent their dwellings from AirBnB platform more than the specified limits. By doing so, the Czech government can also ask AirBnB service providers to make registration in tax offices. Except for tax and other regulations to reduce disruptions in the accommodation market of Prague, the state can also require Airbnb hosts to have licenses. Hosts or users who do not register or do not have permissions can be fined. By doing so, the state not only gains income but also increases the safety and health conditions of these accommodation options. According to Kljucnikov et al. (2018), $7.4 \%$ of Airbnb users tried to rent $39.56 \%$ of the total number of rental properties in Prague. It shows that commercial operators were active for short-term AirBnB rental accommodations in Prague. Therefore, Czech policymakers can also limit the number of rentals that each host can offer as Barcelona, Paris and New York do it.

Conclusions. By playing a significant role in sharing economy, Airbnb provides social and economic benefits for guests that can stay with local people and pay available accommodation costs. This sharing economy platform also enables job opportunities for local landlords and increase their incomes. However, access of AirBnB services into markets can be perceived as an alarming issue for service providers in the hospitality industry, policymakers and local inhabitants because they can cause tax evasion, reduction in revenues of hotels and increase costs of accommodation. For these reasons, this study purposes of determining potential tax evasion that AirBnB residential premises and hosts can create in Prague. Moreover, by assuming some annual limits for overnight staying in these rental dwellings, the study investigates potential troubles that can be seen in supply, demand and costs of accommodations in Prague. The limits are set for 10, 20,30 and 40 days.

Web scrapping method used to collect data from the Airbnb website and this data validated by using Air DNA data. The research data consisted of 13918 rental residences and 6768 users that performed renting activities between April 2016 and March 2017. To measure tax evasion and the number of potential accommodations that might appear in Prague, the researchers used Microsoft Excel 2016 program. Possible tax evasion also calculated by a model that the researchers of this study created.

According to findings, incomes from AirBnB properties in the selected period reached $\$ 86.348 .464$, while $82,53 \%$ of this amount was gained by dwellings that were rented for more than ten days. In comparison with taxing rental properties, taxing AirBnB users induced a lower amount of tax evasion. The reason for this difference between the amounts of tax evasions for both scenarios might be users that 
rented more than one accommodation via the Airbnb platform. The changes in the limits for the number of overnight stays from 10 days to 40 days lower potential tax income of the state just $0.98 \%$ when all properties considered and $6.40 \%$ when all users are considered. Another significant result of this research is that prolonging limits for overnight stays in residential premises reveals a lower number of required accommodations in Prague. Changes in the limits from 10 to 40 days, make the number of needed rental dwellings to differ from 107710 to 16832 . Therefore, applying higher overnight staying limits for rental properties can be a better solution when policymakers need to regulate supply, demand and costs of the short and long-term accommodation market.

Other policy implementations are also provided to overcome problems that Airbnb residential promises might create. For instance, policymakers can charge hosts by additional taxes such as occupancy rate and require licenses. Governments can also direct hosts to rent their dwellings for long-term instead of short term. But policymakers should consider all players that can be affected by AirBnB activities and should create a balance between them. Policymakers might also limit the number of rental flats that each host can offer. Although this study analyzes potential issues that might come into existence in the accommodation sector, it has some limitations. It is limited with only transactions that performed through AirBnB platform in a year.

Moreover, the research only considered rental residences in Prague and the density of these dwellings in the city centre have not taken into consideration. For these reasons, further studies can analyze these issues by focusing on more transactions that perform in a more prolonged period. Researchers can also examine other home-sharing platforms and compare them to widen their studies. More residential premises from different cities and other potential problems can also be included and investigated by new researches.

Author Contributions: conceptualization, A. K., M. C.; methodology, A. K., M. C.; validation, M. C., A. K.; resources, A. K., V. K.; data curation, A. K., V. K.; writing-original draft preparation M. C.; writingreview and editing A. K., L. K.; visualization M. C.; supervision, V. K., L. K.; project administration, A. K., V.K.

\section{References}

About us (2019). Airbnb. Retrieved from https://press.airbnb.com/about-us Accessed: 03.03.2019

Alizadeh, T., Farid, Z. \& Sarkar, S. (2018). Towards Understanding the Socio-Economic Patterns of Sharing Economy in Australia: An Investigation of Airbnb Listings in Sydney and Melbourne Metropolitan Regions, Urban Policy and Research. [Google Scholar] [CrossRef]

Balck, B., \& Cracau, D. (2015). Empirical Analysis of Consumer Motives in the Shareconomy: A Cross-Sectoral Comparison. University of Magdeburg Working Paper No. 2/2015. [Google Scholar] Retrieved from https://ideas.repec.org/p/mag/wpaper/150002.html Accessed: 05.03.2020

Barron, K., Kung, E. \& Proserpio, D. (2018). The Sharing Economy and Housing Affordability: Evidence from Airbnb (March 29, 2018). [Google Scholar] [CrossRef]

Cheng, M. (2016). Sharing economy: A Review And Agenda For Future Research. International Journal of Hospitality Management, 57, 60-70. [Google Scholar] [CrossRef]

Cheng, X., Fu, S., \& de Vreede, G. J. (2018). A mixed method investigation of sharing economy driven car-hailing services: Online and offline perspectives. International Journal of Information Management, 41, 57-64. [Google Scholar] [CrossRef]

Choi, K. H., Jung, J., Ryu, S. D., Kim, S. \& Yoon, S. M. (2015). The Relationship between Airbnb and the Hotel Revenue: In the Case of Korea. Indian Journal of Science and Technology, 8(26), [Google Scholar] [CrossRef]

CNN international (2018), Retrieved from https://edition.cnn.com/travel/article/most-visited-cities-euromonitor-2018/index.html Accessed: 12.04.2019

Coyle, D., \& Yu-Cheong, T. (2016). Understanding AirBnB in Fourteen European Cities. The Jean-Jacques Laffont Digital Chair Working Papers. Retrieved from https://www.tsefr.eu/sites/default/files/TSE/documents/ChaireJJL/PolicyPapers/2016_30_12_pp_understanding_airbnb_in_14_european_cities_c oyle yeung v.3.1.pdf. Accessed: 14.02.2019. 
Crommelin, L., Troy, L., Martin, C., \& Pettit, C. (2018, October 2). Is Airbnb a sharing economy superstar? Evidence from five global cities, Urban Policy and Research. [Google Scholar] [CrossRef]

DiNatale, S., Lewis, R., \& Parker, R. (2018). Short-term rentals in small cities in Oregon: Impacts and regulations. Land use policy, 79, 407-423. [Google Scholar] [CrossRef]

Dogru, T., Mody, M., \& Suess, C. (2017). Comparing apples and oranges? Examining the impacts of Airbnb on hote performance in Boston. Boston Hospitality Review, 5(2), 1-15. Retrieved from http://www.bu.edu/bhr/2017/06/07/airbnb-in-boston/.

Eckhardt G.M. \& Bardhi F. (2015) The sharing economy isn't about sharing at all. Harvard Business Review, (January), 1-3. Retrieved from https://hbr.org/2015/01/the-sharingeconomy-isnt-about-sharing-at-all

Expats News (2018). Retrieved from https://news.expats.cz/praguejobs/prague-rent-prices-are-now-higher-than-the-averageczech-salary/ Accessed: 11.04.2019

Forbes, 2018. Retrieved from https://www.forbes.com/sites/greatspeculations/2018/05/11/as-a-rare-profitable-unicorn-airbnbappears-to-be-worth-at-least-38-billion/\#58a123922741. Accessed: 18.03.2019

Gunter, U. (2018). What makes an Airbnb host a superhost? Empirical evidence from San Francisco and the Bay Area. Tourism Management, 66, 26-37. [Google Scholar] [CrossRef]

Gurran, N. (2018). Global Home-Sharing, Local Communities and the Airbnb Debate: A Planning Research Agenda. Planning Theory \& Practice, 19(2), 298-304. [Google Scholar] [CrossRef]

Gurran, N., \& Phibbs, P. (2017). When tourists move in: How should urban planners respond to Airbnb? Journal of the American Planning Association, 83(1), 80-92. [Google Scholar] [CrossRef]

Heo, C. Y., Blal, I., \& Choi, M. (2019). What is happening in Paris? Airbnb, hotels, and the Parisian market: A case Study. Tourism Management, 70, 78-88. [Google Shcolar] [CrossRef]

Horn, K., \& Merante, M. (2017). Is home sharing driving up rents? Evidence from Airbnb in Boston. Journal of Housing Economics, 38, 14-24. [Google Scholar] [CrossRef]

Kljucnikov, A., Krajcik, V., Vincúrová, Z. (2018). International Sharing Economy: The Case of AirBnB in the Czech Republic. Economics and Sociology, 11(2), 126-137. [Google Scholar] [CrossRef]

Lambea Llop, N. (2017). A policy approach to the impact of tourist dwellings in condominiums and neighbourhoods in Barcelona. Urban Research \& Practice, 10(1), 120-129. [Google Scholar] [CrossRef]

Melo, S., Macedo, J. \& Baptista, P. (2019). Capacity-Sharing In Logistics Solutions: A New Pathway Towards Sustainability. Transport Policy, 73, 143-151. [Google Scholar] [CrossRef]

Olivo, A. (2018). Fairfax County adopts rules taxing Airbnb-style rentals. The Washington Post (Online), Washington, D.C.: WP Company LLC d/b/a The Washington Post. Aug 2, 2018 Retrived from https://www.washingtonpost.com/local/virginia-politics/fairfaxadopts-rules-taxing-airbnb-style-rentals/2018/08/02/fd369bbc-95d5-11e8-a679-b09212fb69c2_story.html

Oskam, J. \& Boswijk, A. (2016). Airbnb: the future of networked hospitality businesses. Journal of Tourism Futures, 2(1), 22 -

42. [Google Sholar] [CrossRef]

Prague City Tourism Annual Report, (2017). Information about Prague, Annual report Prague city tourism Retrieved from https://www.praguecitytourism.cz/file/edee/en/annual-reports/a4-vyrocni-zprava-2018 2-verze en web.pdf.Accessed: 09.04.2019 Quattrone, G., Proserpio, D., Quercia, D., Capra, L. \& Musolesi, M. (2016, April). Who Benefits from the "Sharing" Economy of Airbnb? In Proceedings of the 25th international conference on world wide web (pp. 1385-1394). [Google Scholar] [CrossRef]

Quinby, D. \& M. Gasdia. (2014). Share This! Private Accommodation and the Rise of the New Gen Renters. Report. PhoCusWright. Retrieved from https://www.phocuswright.com/Travel-Research/Research-Updates/2014/Share-This-PrivateAccommodation-the-Rise-of-the-New-Gen-Renter Accessed: 04.03.2020.

Richman, T. (2018). Proposed 'Airbnb bill' could generate up to $\$ 1$ million in hotel tax revenues, analysis shows. The Baltimore Sun (Online), Baltimore: Tribune Interactive, LLC. Jul 19, 2018. Retrieved from https://www.baltimoresun.com/maryland/baltimorecity/bs-md-ci-airbnb-hearing-20180718-story.html

Schafer, P., \& Braun, N. (2016). Misuse through short-term rentals on the Berlin housing market. International Journal of Housing Markets and Analysis, 9 (2), 287-311. [Google Sholar] [CrossRef]

Sharp, D. (2018). Sharing Cities for Urban Transformation: Narrative, Policy and Practice. Urban Policy and Research, 36(4), 513-526. [Google Scholar] [CrossRef]

Sheppard, S., \& Udell, A. (2016). Do Airbnb properties affect house prices? Williams College Department of Economics Working Papers, 3, 1-45. [Google Scholar]

Skalska, T., \& Shcherbiak, E. (2016). The Competitiveness on the Tourism Market: Airbnb as Challenge for Small Enterprises in the Tourism Sector: Analysis of Prices of Accommodation Services on the Examples of Cities with Strong Tourist Function. Przedsiębiorczosc i Zarządzanie, 177), cz. 2 Zarządzanie małym i srednim przedsiębiorstwem w Polsce: innowacyjne strategie, narzędzia i wdrozenia), 193-211. [Google Sholar] Retrieved from: http://piz.san.edu.pl/docs/e-XVII-7-2.pdf Accessed: 05.03.2020

Stuchly, J., \& Suta, M. (2019). Participation In The Sharing Economy In The Czech Republic. In SHS Web of Conferences (Vol. 61, p. 01025). EDP Sciences. [Google Scholar] [CrossRef]

Trading Economics, House Price Index (2019). Retrieved from https://tradingeconomics.com/czech-republic/housingindex Accessed: 10.04.2019

Tussyadiah, I. P. \& Pesonen, J. (2015). Impacts of Peer-to-Peer Accommodation Use on Travel Patterns. Journal of Trave/ 
Research, 55(8), 1022-1040. [Google Scholar] [CrossRef]

Wachsmuth, D., \& Weisler, A. (2018). Airbnb and the rent gap: Gentrification through the sharing economy. Environment and Planning A: Economy and Space, 50(6), 1147-1170. [Google Scholar] [CrossRef]

Wegmann, J. \& Jiao, J. (2017). Taming Airbnb: Toward guiding principles for local regulation of urban vacation rentals based on empirical results from five US cities. Land Use Policy, 69, 494-501. [Google Scholar]

Zervas, G., Proserpio, D. \& Byers, J. W. (2017). The Rise of the Sharing Economy: Estimating the Impact of Airbnb on the Hotel Industry. Journal of Marketing Research, 54(5), 687-705. [Google Scholar] [CrossRef]

Zhang, T., Bufquin, D., \& Lu, C. (2019). A qualitative investigation of microentrepreneurship in the sharing economy. International Journal of Hospitality Management, 79, 148-157. [Google Scholar] [CrossRef]

Zuo, W., Zhu, W., Chen, S., \& He, X. (2019). Service quality management of online car-hailing based on PCN in the sharing economy. Electronic Commerce Research and Applications, 34, 100827. [Google Scholar] [CrossRef]

Олександр Ключніков, Ph.D., Університет підприемництва та права (Чеська Республіка);

Мехмет Цивелек, Ph.D., Університет підприємництва та права (Чеська Республіка);

Володимир Крайчик, Ph.D., Університетський коледж бізнесу в Празі (Чеська Республіка);

Любомир Кмеко, Ph.D., Університетський коледж бізнесу в Празі (Чеська Республіка).

Інновації в туристичному маркетингу: шерингові платформи

Метою статті $є$ аналіз інноваційної діяльності в туристичному маркетингу та шеринговій економіці на прикладі Airbnb в Празі. Авторами систематизовано аргументи та контраргументи у рамках наукової дискусії щодо ухилення від сплати податків, а також підвищення ставок на орендну оплату для житлових приміщень, що пропонують шерингові платформи. У статті проаналізовано та систематизовано потенційні проблеми, що виникають на ринку оренди житла. Систематизація результатів аналізу наукових джерел дозволила визначити низку переваг та недоліків функціонування платформ шерингової економіки. Детерміновану вибірку даних сформовано на основі методу веб-аналізу даних із офіційного сайту АігВпB. У статті проаналізовано 13918 пропозицій житла, які були орендовані 6768 клієнтами АігВпВ з квітня 2016 року по березень 2017. При цьому практичну реалізацію етапів дослідження здійснено з використанням програми Microsoft Excel 2016, а також економетричної моделі, розробленої автором. Результати проведеного емпіричного дослідження свідчать про те, що регулювання податкових ставок в залежності від кількості орендованих ночей призведе до зниження податкових надходжень від оренди житла на 0,98\%. Визначено, що при встановленні схеми оподаткування при якій клієнт сплачує податки за оренду, зниження податкових надходжень становитиме 6,40\%. Авторами доведено, що зміна системи оподаткування призведе до відкритості довгострокового ринку житла, що обумовить зростання пропозиції житла для оренди на 16832 одиниць. У статті обгрунтовано, що при розрахунку суми податків за оренду житла в розрізі їх власників забезпечує меншу суму податкових надходжень, аніж при розрахунку податку за кожне орендоване житло. Авторами емпірично підтверджено та теоретично доведено, що введення гнучкої системи оподаткування в залежності від тривалості оренди $є$ більш вигідними з точки зору витрат, пропозиції та попиту на оренду приміщень. Результати дослідження мають практичне значення і можуть бути корисними державним органам, науковцям, які зацікавлені в дослідженні питань туристичного маркетингу, компаніям житлової галузі, які впроваджують маркетингові інновації,' а також суб'єктам ринку житлових послуг, таких як орендодавці та орендатори, у короткостроковій та довгостроковій перспективі.

Ключові слова: житлове приміщення, туризм, маркетинг, Airbnb, інновації, шеринг житла, Прага, економіка спільного доступу, оподаткування.

Manuscript received:21.10.2019.

(c) The author(s) 2020. This article is published with open access at Sumy State University. 